The Israeli J ournal of Aquaculture - Bamidgeh, IJ A_69.2017.1393, 10 pages

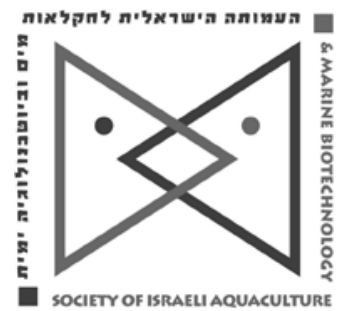

The IJ A appears exclusively as a peer-reviewed on-line

open-access journal at http://www. siamb.org.il. To read papers free of charge, please register online at registration form.

Sale of IJA papers is strictly forbidden.

\title{
The Effect of Distiller's Dried Grains with Solubles on Carcass Composition, Fatty Acid Composition, Skin and Fillet Coloration of Rainbow Trout (Oncorhynchus mykiss)
}

\author{
Baki Aydın ${ }^{1}$, Serpil Yılmaz $^{1}$, Erkan Gümüş ${ }^{1 *}$ \\ ${ }^{1}$ Fisheries Faculty, Akdeniz University, Antalya, Turkey
}

Keywords: DDGS; fish meal; alternative feedstuff; sustainable diets;

flesh quality; colour

\begin{abstract}
The aim of the study was to evaluate the effects of distiller's dried grains with solubles (DDGS) as an alternative protein source on carcass composition, fatty acid composition, skin, and fillet coloration of rainbow trout (Oncorhynchus mykiss). Four isoproteic (45.5\% crude protein) and isocaloric $(17.42 \mathrm{MJ} / \mathrm{kg})$ diets were formulated using DDGS $(0,10,20$ and $30 \%)$ for a feeding trial of 84 days. Fish (mean initial weight of $19.88 \mathrm{~g}$ ) were distributed into triplicate treatments at a rate of 25 fish per $200 \mathrm{~L}$ tanks and fed to satiation with the experimental diets three times a day. The results of the present study show that the coloration of experimental fish was not modified negatively by the use of DDGS protein sources in diets. Carcass composition values were also not affected by increased DDGS, although some fatty acids were affected. Total saturated fatty acids, total monounsaturated fatty acids, total n-3 polyunsaturated fatty acids ( $\sum n-3$ PUFA) and $\sum n-3$ PUFA/total n- 6 polyunsaturated fatty acids ( $\sum n-6$ PUFA) values of the fish in the experimental groups were found to be statistically similar. On the other hand, palmiteloic acid, docosahexaenoic acid and $\Sigma$ n-3 PUFA decreased, while linoleic acid, $\Sigma n-$ 6 PUFA and $\Sigma$ PUFA increased significantly. In conclusion, the fatty acid composition of fish muscle was affected by the use of DDGS up to a rate of $30 \%$ in rainbow trout diet, while no negative effect on the skin and fillet coloration could be found.
\end{abstract}

Corresponding author: Tel.: +90 24231066 36, fax: +90 242226 2013, e-mail: egumus@akdeniz.edu.tr 
Aydin et al.

\section{I ntroduction}

Fish meal (FM) has been widely used in carnivorous fish feed as a high-quality feed ingredient. FM production cannot meet the increasing demand as fish stocks worldwide are diminishing, and costs are high relative to other protein sources. In an attempt to solve the impending crisis in the expanding aquaculture sector, research on cheaper and plentiful vegetal or animal protein source alternatives to replace FM has increased. Distiller's dried grains with solubles (DDGS), a major by-product of the dry mill ethanol industry, is a vegetal protein source which is readily available, has high feeding values, and is competitively priced relative to other alternative protein sources (Magalhães et al., 2015). Studies regarding replacement of lowered FM with DDGS as an alternative feed protein source have been carried out on cultured fish species like rainbow trout Oncorhynchus mykiss (Barnes et al., 2012), European seabass Dicentrarchus labrax, meagre Argyrosomus regius (Magalhães et al., 2015), and the Nile tilapia Oreochromis niloticus (Schaeffer et al., 2010).

Research into complete or partial replacement of FM with vegetal alternative protein sources has had both positive and negative changes on fish skin, fillet coloration, and quality (Kalinowski et al., 2005; James et. al., 2009; García-Romero et al., 2014; Aydın et al., 2015; Yi et al., 2015; Grassi et al., 2016; Karadal et al., 2016). Some studies have shown negative effects of vegetal protein source replacement for $F M$ on the chemical composition, a lowering of $\mathrm{n}-3$ and polyunsaturated fatty acid (PUFA) values as compared to the fish fed with FM (Francesco et al., 2004; Gümüş and Aydın, 2013; Aydın et al., 2015). Others have shown that partial substitution does not affect body composition of tilapias (Yigit and Demir, 2016). Changes in color and quality of the fish directly affect price and preference (Kalinowski et al., 2011). Therefore, some research has been focused on the effects of the feed content on skin and fillet color (Francesco et al., 2004; Kalinowski et al., 2005; García-Romero et al., 2014; Yi et al., 2015; Karadal et al., 2016). Although several studies have examined the effects of DDGS on coloration on poultry and livestock (Cortes-Cuevas et al., 2015), no reports on the effects of DDGS supplementation to fish feed are available.

The aim of this study was to investigate the effects of partial replacement of FM with DDGS on carcass composition, muscle fatty acid composition, skin, and fillet coloration of rainbow trout (Oncorhynchus mykiss).

\section{Materials and Methods}

Feed formulation and preparation. The fish meal (FM) used as the protein source in experimental feeds was obtained from Skretting Feed Production Co. Inc. (İzmir, Turkey), and the distillers dried grains with solubles (DDGS) made of corn was obtained from Agricultural Chemistry Technologies Ind. and Co. Inc. (Bursa, Turkey).

Four isoproteic $(45.47 \%$ crude protein) and isocaloric (17.42 MJ/kg digestible energy) experimental diets were formulated using DDGS (0 [Control], 10 [DDGS10], 20 [DDGS20], and 30\% [DDGS30]) to meet NRC (2011) requirements for rainbow trout (Oncorhynchus mykiss) (Table 1 ). The ground feed content was weighed using digital balances with $0.5 \mathrm{~g}$ (KERN DS 65K) and $0.001 \mathrm{~g}$ precision (Scaltec SPB 42), homogenized in a food mixer (Jinan Eagle Machine DP-40, Shandong, China), then pelleted using a twin-screw extruder (DP65-II Twin Screw Inflating Food Machine, Jinan Eagle Machine Co., Ltd., Shandong, China) into $3 \mathrm{~mm}$ pellets. After decreasing the moisture content below $11.5 \%$ using a ventilated oven (DP-DKX-II Multi-Layer Auto Oven, Jinan Dapeng Machine Co., Ltd., Shandong, China) the food contents were left to cool down at room temperature and stored in sealed plastic bags at below $-20^{\circ} \mathrm{C}$ for future use. 
Table 1. Feed ingredients and proximate composition of the experimental diets

\begin{tabular}{|c|c|c|c|c|}
\hline \multirow[b]{2}{*}{ Ingredients (\%) } & \multicolumn{4}{|c|}{ Experimental diets $^{1}$} \\
\hline & $\begin{array}{l}\text { DDGSO } \\
\text { (Control) }\end{array}$ & DDGS10 & DDGS20 & DDGS30 \\
\hline Fish meal $^{2}$ & 65.00 & 61.38 & 57.77 & 54.16 \\
\hline DDGS $^{3}$ & 0.00 & 10.00 & 20.00 & 30.00 \\
\hline Corn starch & 25.50 & 19.57 & 13.63 & 7.67 \\
\hline Fish oil & 6.00 & 5.55 & 5.10 & 4.67 \\
\hline Vitamin premix ${ }^{4}$ & 1.00 & 1.00 & 1.00 & 1.00 \\
\hline Mineral premix ${ }^{5}$ & 1.00 & 1.00 & 1.00 & 1.00 \\
\hline $\mathrm{CMC}^{6}$ & 1.00 & 1.00 & 1.00 & 1.00 \\
\hline $\mathrm{Cr}_{2} \mathrm{O}_{3}{ }^{7}$ & 0.50 & 0.50 & 0.50 & 0.50 \\
\hline \multicolumn{5}{|c|}{ Proximate composition ${ }^{8}$} \\
\hline Dry matter (\%) & 89.24 & 89.14 & 88.84 & 88.54 \\
\hline Crude protein (\%) & 43.79 & 43.32 & 43.44 & 43.87 \\
\hline Crude lipid (\%) & 12.18 & 12.48 & 12.96 & 13.24 \\
\hline Crude ash (\%) & 9.34 & 9.32 & 9.41 & 9.34 \\
\hline Crude fibre (\%) & 1.24 & 1.78 & 2.36 & 2.98 \\
\hline $\operatorname{NFE}(\%)^{9}$ & 22.69 & 22.25 & 20.67 & 19.12 \\
\hline $\mathrm{DE}(\mathrm{MJ} / \mathrm{kg})^{10}$ & 17.42 & 17.43 & 17.45 & 17.47 \\
\hline
\end{tabular}

${ }^{1}$ Experimental diet code indicating DDGS in diet $(0 \%, 10 \%, 20 \%$, and $30 \%$, respectively);

${ }^{2}$ Anchovy Engraulis encrasicolus, Black sea. Crude protein $69.8 \%$, crude lipid $10.4 \%$ (wet weight)

${ }^{3}$ Distiller's dried grains with solubles. Crude protein $25.5 \%$, crude lipid $12.2 \%$ (wet weight)

${ }^{4}$ Per kg vitamin mix (Rovimix 107): 16000000 IU vitamin A, 1600000 IU vitamin D3, $170000 \mathrm{mg}$ vitamin E, $10800 \mathrm{mg}$ vitamin K3, $16000 \mathrm{mg}$ vitamin B1, 25500 $\mathrm{mg}$ vitamin B2, $17000 \mathrm{mg}$ vitamin B6, 43 vitamin B12, $170000 \mathrm{mg}$ vitamin C, 170 $000 \mathrm{mg}$ niacin, $5100 \mathrm{mg}$ folic acid, $42500 \mathrm{mg}$ calcium D-pantothenate, $425 \mathrm{mg} \mathrm{D}$ biotin, $255000 \mathrm{mg}$ inositol.

${ }^{5}$ Per kg mineral mix (Remineral): $42500 \mathrm{mg}$ manganese, $42500 \mathrm{mg}$ iron, $42500 \mathrm{mg}$ zinc, $8500 \mathrm{mg}$ copper, $128 \mathrm{mg}$ cobalt, $680 \mathrm{mg}$ iodine, $128 \mathrm{mg}$ selenium

${ }^{6}$ Carboxymethyl cellulose

${ }^{7}$ Chromium oxide

${ }^{8}$ Proximate composition values are mean of triplicate analyses (\%, wet weight basis)

${ }^{9}$ Nitrogen-free extract $=100-(\%$ crude protein $+\%$ crude lipid $+\%$ crude ash + $\%$ crude fiber $+\%$ moisture)

${ }^{10}$ Digestible energy of experimental diets was calculated according to values $20.5 \mathrm{~kJ} / \mathrm{g}$ protein, $37.7 \mathrm{~kJ} / \mathrm{g}$ fat, and $14.6 \mathrm{~kJ} / \mathrm{g}$ carbohydrate (Aydın and Gümüş, 2013)

Rearing conditions of fish and feeding. This study was conducted at the Toklu Fish Farm Co., Ltd. (Antalya, Turkey), between January 1 and March 29 of 2015. The rainbow trout (Oncorhynchus mykiss Walbaum, 1792) were obtained from Aydemir Trout Co., Ltd. (Isparta, Turkey). During the acclimation period of 15 days the fish were fed $3 \mathrm{~mm}$ diameter commercial trout feed composed of $45 \%$ crude protein, $18 \%$ crude lipid and 16.7 MJ/kg energy (Blueaq, Abalıoğlu Feed-Soy and Textile Ind. Inc., Denizli, Turkey). At the beginning of the experiment, each of 12 cylindrical fiberglass tank ( $200 \mathrm{~L}$ water/tank) was randomly stocked with 25 fish (initial mean weight of $19.88 \pm 0.02 \mathrm{~g}$ ) with three replicate tanks for each dietary treatment ( 4 treatments $\times 3$ replicates). Each tank was supplied with $10 \mathrm{~L} / \mathrm{min}$ flow-through freshwater at a temperature, 14.3 $\pm 1.2^{\circ} \mathrm{C}$; dissolved oxygen, $8.4 \pm 0.4 \mathrm{mg} / \mathrm{L}$; and $\mathrm{pH} 7.2 \pm 0.1$. Fish were fed by hand to apparent satiation with experimental diets three times a day (09:00, 13:00 and 17:00 h) for 84 days. Photoperiod was set at natural conditions. Fish weight and amount of feed consumed was measured biweekly. Any uneaten feed was collected $1 \mathrm{~h}$ after each feeding, dried to constant weight at $70^{\circ} \mathrm{C}$ and weighed.

Chemical analysis. At the end of the trial, five fish per tank were selected and anesthetized with $0.75 \mathrm{ml} / \mathrm{L}$ clove oil solution (1:10 ratio; clove oil: $95 \%$ ethanol). Fish samples were stored at $-20^{\circ} \mathrm{C}$ until they were analysed for proximate carcass and muscle fatty acids composition. Chemical composition of experimental diets and fish carcass 
were performed according to standard AOAC (1995). Moisture was determined by drying to constant weight at $105^{\circ} \mathrm{C}$ in laboratory oven (Elekro-mag M 5040 p), crude protein ( $N$ $\times$ 6.25) was determined by the Kjeldahl method after an acid digestion (Gerhardt Analytical Systems; Königswinter, Germany), crude lipid was determined by the etherextraction method using the Soxtec System HT (Behr Soxtec System KV5M; Düsseldorf, Germany), and ash content was determined by a muffle furnace (Elekro-mag M 1813) at $550^{\circ} \mathrm{C}$ for $5 \mathrm{~h}$. Total lipids were extracted by the method of Folch et al. (1957). Fatty acids were methylated according to the procedure of Metcalfe and Schmitz (1961) and fatty acid methyl esters (FAME) were analyzed as described by Czesny and Dabrowski (1998). Fatty acids were determined by Agilent 6890 N Network Gas Chromatography (Agilent Technologies; Santa Clara, CA, United States).

Color measurements. At the end of the feeding experiment, five fish from each tank were randomly selected and anesthetized with $0.75 \mathrm{ml} / \mathrm{L}$ clove oil solution for color measurements. Color measurements were taken at the end of the procedure (Average weight of these fish: $104.1 \pm 11.0 \mathrm{~g}$ ) using a Minolta CR400 Chroma Meter (Minolta Camera Co. Ltd., Asaka, Japan). Triplicate measurements were taken at each site, to obtain a mean value for each area. The color measurements were performed on the left body surface area of each fish. Skin color measurements were performed at three sites (Kalinowski et al. 2005): opercular site above the lateral line $1 \mathrm{~cm}$ posterior to the operculum, dorsal site $1 \mathrm{~cm}$ below the dorsal fin, and the caudal site just above the lateral line in line with anal fin (Fig. 1). Fillet color measurements were performed at two different sites (the dorsal and caudal sites) after removal of the fillets. Color measurements of FM, and DDGS were performed in petri dishes. Data for each sample was expressed in terms of International Commission on Illumination CIE (1976) values for $\mathrm{L}^{*}$ (lightness), a* (redness) and $\mathrm{b}^{*}$ (yellowness). Angle of hue $\left(\mathrm{H}^{*}\right)$ and chroma ( $\left.\mathrm{C}^{*}\right)$ which defines the saturation of color were calculated by the equation, $\mathrm{H}^{*}=\arctan$ $\left(b^{*} / a^{*}\right)$ and $C^{*}=\left(a^{*}+b^{* 2}\right)^{1 / 2}$, respectively (Hunt, 1977). Referential A standard white tile with reflectance values of $L^{*}=95.23, a=-0.31$ and $b=+3.01$ was used as the reference.

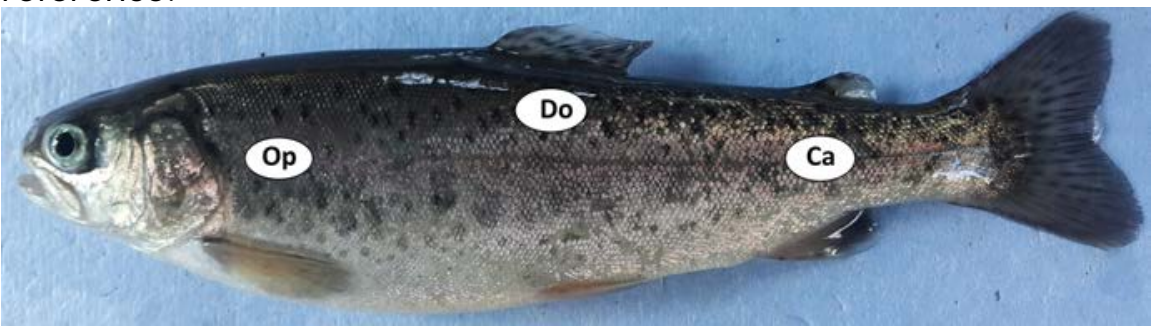

Fig. 1. Location of skin and fillet color measurement sites on a rainbow trout. Op: Opercular site, Do: Dorsal site,

Ca: Caudal site (Original photo).

Statistical analysis. All data were subjected to one-way analysis of variance (ANOVA) using the software of the SPSS 22.0 (SPSS INC., Chicago, IL, USA). Differences among the means were compared by Duncan's multiple range test at a $5 \%$ probability level. All data were presented as mean \pm standard deviation (mean \pm SD) throughout the text.

\section{Results}

Proximate composition. The proximate carcass composition values of the rainbow trout after 84 days of feeding with the experimental feeds containing DDGS as protein source replacement for FM for are given in Table 2. According to the statistical analyses made, no significant differences among the experimental groups regarding the carcass moisture, crude protein, crude lipid and crude ash $(P>0.05)$.

Table 2. Proximate carcass composition of rainbow trout fed the experimental diets

\begin{tabular}{|c|c|c|c|c|}
\hline \multirow[b]{2}{*}{ Parameters ${ }^{2}$} & \multicolumn{4}{|c|}{ Experimental diets $^{1}$} \\
\hline & Control & DDGS10 & DDGS20 & DDGS30 \\
\hline Moisture (\%) & $68.04 \pm 0.87$ & $69.08 \pm 0.62$ & $68.13 \pm 0.76$ & $67.92 \pm 0.40$ \\
\hline $\begin{array}{l}\text { Crude protein (\%) } \\
\text { Crude lipid }(\%)\end{array}$ & $\begin{array}{l}18.33 \pm 0.33 \\
10.57 \pm 0.42\end{array}$ & $\begin{array}{l}18.23 \pm 0.39 \\
10.38 \pm 0.55\end{array}$ & $\begin{array}{l}18.47 \pm 0.65 \\
10.71 \pm 0.73\end{array}$ & $\begin{array}{l}18.95 \pm 0.47 \\
10.82 \pm 0.16\end{array}$ \\
\hline Crude ash (\%) & $1.68 \pm 0.03$ & $1.67 \pm 0.09$ & $1.72 \pm 0.05$ & $1.73 \pm 0.04$ \\
\hline
\end{tabular}

${ }^{1}$ Experimental diet code indicating DDGS in diet $(0 \%, 10 \%, 20 \% \text {, and } 30 \% \text {, respectively })^{2}$ No significant difference among means according to one-way variance analysis $(P>0.05)$.

Values are mean of triplicate analysis. Crude protein, crude lipid and crude ash values are given over wet weight 
Fatty acid composition. At the end of the experiment, fatty acid composition in the fish muscles of the treatment groups is given in Table 3. No statistically significant effect of partial replacement of FM with DDGS on saturated fatty acids (SFA) could be observed $(P>0.05)$, as can be seen in $\Sigma$ SFA (Table 3$)$. Despite a statistically significant decrease in palmiteloic acid (C16:1) in DDGS20 and DDGS30 group, the DDGS ratio supplementation in the feed did not significantly influence the other monounsaturated fatty acids (MUFA) and $\Sigma$ MUFA values. Among the $\mathrm{n}-3$ series polyunsaturated acids (PUFA) of the DDGS20 group eicosapentaenoic acid (C20:5n-3; EPA) was significantly lower compared to the control group $(P<0.05)$, no significant difference between the DDGS30 group and the control could be seen $(P>0.05)$. Also no significant difference was found among groups in a-linolenic acid (C18:3n-3), eicosatrienoic acid (C20:3n-3), docosahexaenoic acid $(\mathrm{C} 22: 6 n-3 ; \mathrm{DHA})$ and $\sum \mathrm{n}-3$ PUFA values $(P>0.05)$. Among the $n-6$ series fatty acids, linoleic acid $(C 18: 2 n-6)$ value increased along with the DDGS increase in feed, as did the $\Sigma n-6$ PUFA value $(P<0.05)$. $\Sigma$ PUFA and the $\Sigma n-3 / \Sigma n-6$ ratio were also found to be similar among the groups $(P>0.05)$.

Table 3. The fatty acid composition of rainbow trout fed the experimental diets

\begin{tabular}{|c|c|c|c|c|}
\hline \multirow{2}{*}{$\begin{array}{l}\text { Fatty acids }{ }^{2} \\
\text { ( } \%, \text { on total fatty } \\
\text { acids) }\end{array}$} & \multicolumn{4}{|c|}{ Experimental diets $^{1}$} \\
\hline & Control & DDGS10 & DDGS20 & DDGS30 \\
\hline C14: 0 & $4.16 \pm 0.18$ & $4.28 \pm 0.26$ & $3.88 \pm 0.24$ & $4.01 \pm 0.41$ \\
\hline C15: 0 & $0.78 \pm 0.16$ & $0.83 \pm 0.23$ & $1.19 \pm 0.48$ & $0.94 \pm 0.57$ \\
\hline C16: 0 & $23.16 \pm 2.03$ & $23.13 \pm 1.51$ & $25.56 \pm 1.85$ & $23.82 \pm 4.12$ \\
\hline C17:0 & $1.29 \pm 0.45$ & $1.31 \pm 0.52$ & $1.63 \pm 0.50$ & $0.98 \pm 0.06$ \\
\hline C18: 0 & $5.75 \pm 0.53$ & $5.69 \pm 0.62$ & $5.98 \pm 0.34$ & $5.56 \pm 0.14$ \\
\hline C20: 0 & $0.57 \pm 0.18$ & $0.52 \pm 0.23$ & $0.54 \pm 0.21$ & $0.48 \pm 0.02$ \\
\hline C21:0 & $0.55 \pm 0.07$ & $0.73 \pm 0.09$ & $0.85 \pm 0.08$ & $0.82 \pm 0.28$ \\
\hline C23: 0 & $0.49 \pm 0.07$ & $0.45 \pm 0.02$ & $0.42 \pm 0.12$ & $0.41 \pm 0.05$ \\
\hline$\Sigma S F A^{3}$ & $36.76 \pm 3.50$ & $36.92 \pm 3.03$ & $40.05 \pm 2.89$ & $37.02 \pm 5.26$ \\
\hline C16: 1 & $5.53 \pm 0.11^{\mathrm{a}}$ & $5.71 \pm 0.94^{a}$ & $4.44 \pm 0.10^{\mathrm{b}}$ & $4.47 \pm 0.11^{b}$ \\
\hline C18: 1n-9 & $25.81 \pm 1.50$ & $25.26 \pm 2.49$ & $24.83 \pm 1.30$ & $26.38 \pm 1.13$ \\
\hline C20: 1n-9 & $1.49 \pm 0.19^{a}$ & $1.44 \pm 0.12^{\mathrm{a}}$ & $1.05 \pm 0.09^{b}$ & $1.39 \pm 0.07^{a}$ \\
\hline$C 22: 1 n-9$ & $0.69 \pm 0.13$ & $0.82 \pm 0.13$ & $0.80 \pm 0.23$ & $0.66 \pm 0.04$ \\
\hline$\Sigma M_{U} A^{4}$ & $33.52 \pm 1.85$ & $33.23 \pm 3.21$ & $31.12 \pm 1.38$ & $32.89 \pm 1.21$ \\
\hline C18: 3n-3 & $1.28 \pm 0.03$ & $1.19 \pm 0.05$ & $1.18 \pm 0.24$ & $1.17 \pm 0.05$ \\
\hline$C 20: 3 n-3$ & $0.14 \pm 0.06$ & $0.14 \pm 0.04$ & $0.12 \pm 0.02$ & $0.11 \pm 0.02$ \\
\hline C20: 5n-3 (EPA) & $2.49 \pm 1.24^{a}$ & $2.25 \pm 1.52^{\mathrm{ab}}$ & $1.74 \pm 0.53^{b}$ & $2.16 \pm 0.04^{\mathrm{ab}}$ \\
\hline C22:6n-3 (DHA) & $12.00 \pm 1.16$ & $11.69 \pm 4.29$ & $9.49 \pm 0.62$ & $11.05 \pm 1.44$ \\
\hline$\Sigma n-3$ PUFA $^{5}$ & $15.92 \pm 1.25$ & $15.26 \pm 4.73$ & $12.52 \pm 0.90$ & $14.49 \pm 1.45$ \\
\hline C18:2n-6 & $10.01 \pm 2.07^{c}$ & $9.32 \pm 0.90^{c}$ & $12.75 \pm 0.52^{b}$ & $15.49 \pm 1.06^{a}$ \\
\hline$C 20: 2 n-6$ & $0.72 \pm 0.16$ & $0.86 \pm 0.42$ & $0.87 \pm 0.12$ & $0.88 \pm 0.10$ \\
\hline$C 20: 3 n-6$ & $0.22 \pm 0.04$ & $0.24 \pm 0.07$ & $0.34 \pm 0.13$ & $0.33 \pm 0.11$ \\
\hline$C 20: 4 n-6$ & $0.17 \pm 0.02$ & $0.19 \pm 0.02$ & $0.21 \pm 0.04$ & $0.21 \pm 0.04$ \\
\hline$\Sigma n-6$ PUFA $^{6}$ & $11.24 \pm 2.09^{c}$ & $10.70 \pm 1.17^{c}$ & $14.17 \pm 0.75^{b}$ & $17.02 \pm 1.30^{a}$ \\
\hline$\Sigma \mathrm{PUFA}^{7}$ & $27.16 \pm 3.31^{\mathrm{ab}}$ & $25.96 \pm 3.73^{b}$ & $26.70 \pm 1.62^{a b}$ & $31.51 \pm 0.53^{a}$ \\
\hline$\Sigma n-3 / \Sigma n-6$ & $1.44 \pm 0.18$ & $1.47 \pm 0.58$ & $0.88 \pm 0.02$ & $0.86 \pm 0.15$ \\
\hline $\begin{array}{l}{ }^{1} \text { Experimental diet co } \\
{ }^{2} \text { Fatty acids composit } \\
\text { different superscri } \\
{ }^{3} \text { Total saturated fatty } \\
\text { and C: } 23 \\
{ }^{4} \text { Total monounsaturat } \\
{ }^{5} \text { Total } n-3 \text { polyunsatur } \\
\text { C } 22: 6 n-3 \\
{ }^{6} \text { Total } n-6 \text { polyunsatu } \\
\text { C20: } 4 n-6 \\
{ }^{7} \text { Total polyunsaturate } \\
\text { C20: } 3 n-6, C 20: 5 n\end{array}$ & $\begin{array}{l}\text { indicating DDGS } \\
\mathrm{n} \text { values are mea } \\
\mathrm{s} \text { are significantly } \\
\text { cids included } \mathrm{C} 14 \\
\text { d fatty acids inclu } \\
\text { ted fatty acids in } \\
\text { ted fatty acids in } \\
\text { fatty acids includ }\end{array}$ & $\begin{array}{l}\text { in diet }(0 \%, 10 \\
n \text { of two analysis } \\
\text { different }(P<0 . \\
: 0, C 15: 0, C 16: \\
\text { ded } C 16: 1, C 18 \text { : } \\
\text { cluded } C 18: 3 n-3 \\
\text { cluded } C 18: 2 n-6 \\
\text { ed } C 18: 2 n-6, C 1 \\
C 22: 6 n-3\end{array}$ & $\begin{array}{l}\%, 20 \%, \text { and } 30 \% \\
\text { Values in the } \\
5) \\
1 n-9, C 17: 0, C 18: 0 \text {, } \\
C 20: 3 n-3, C 20 \text {, } \\
\text { C20:2n-6, C20: } \\
8: 3 n-3, C 20: 2 n-6\end{array}$ & $\begin{array}{l}0, \text { respectively) } \\
\text { me row with } \\
C 20: 0, C: 21 \text {, } \\
\text { and } C 22: 1 n-9 \\
5 n-3, \text { and } \\
3 n-6 \text {, and } \\
\text { C20:3n-3, }\end{array}$ \\
\hline
\end{tabular}


Aydin et al.

Color parameters. Coloration data for the diet protein sources (FM and DDGS samples) and the experimental diets are presented in Table 4. DDGS L* (lightness), a* (redness), b* (yellowness), $\mathrm{C}^{*}$ (brightness) and $\mathrm{H}^{*}$ (hue) were found to be higher than that of FM, meaning that DDGS is lighter, with more yellow and red in comparison. Statistical analyses showed that $\mathrm{L}^{*}$ and $\mathrm{H}^{*}$ values were similar among experimental feeds $(P>0.05)$, while $a^{*}, b^{*}$ and $C^{*}$ were significantly different $(P<0.05)$, although this difference is between the control and experimental groups $(P<0.05)$, each being otherwise similar. The higher $b *$ value of the protein source DDGS, is reflected by the higher $b^{*}$ values of the DDGS containing experimental feeds.

Table 4. Color parameters of feed ingredients and experimental diets

\begin{tabular}{lcccccc} 
& & & \multicolumn{4}{c}{ Experimental diets } \\
\cline { 4 - 6 } Parameters & FM & DDGS & Control & DDGS10 & DDGS20 & DDGS30 \\
\hline L* $^{*}$ & $40.90 \pm 2.76$ & $45.06 \pm 2.85$ & $28.61 \pm 0.55$ & $28.76 \pm 0.58$ & $29.10 \pm 0.41$ & $29.40 \pm 0.25$ \\
a $^{*}$ & $-0.13 \pm 0.14$ & $6.43 \pm 0.92$ & $-3.29 \pm 0.11^{\mathrm{a}}$ & $-3.71 \pm 0.12^{\mathrm{b}}$ & $-3.64 \pm 0.14^{\mathrm{b}}$ & $-3.63 \pm 0.14^{\mathrm{b}}$ \\
b* $^{*}$ & $20.47 \pm 0.80$ & $36.36 \pm 0.87$ & $14.82 \pm 0.39^{\mathrm{b}}$ & $16.38 \pm 0.50^{\mathrm{a}}$ & $16.57 \pm 0.92^{\mathrm{a}}$ & $17.14 \pm 0.66^{\mathrm{a}}$ \\
C* $^{*}$ & $20.47 \pm 0.65$ & $36.94 \pm 0.73$ & $15.19 \pm 0.36^{\mathrm{b}}$ & $16.79 \pm 0.51^{\mathrm{a}}$ & $16.97 \pm 0.87^{\mathrm{a}}$ & $17.52 \pm 0.62^{\mathrm{a}}$ \\
h$^{*}$ & $-1.56 \pm 0.01$ & $1.40 \pm 0.02$ & $-1.35 \pm 0.01$ & $-1.35 \pm 0.01$ & $-1.35 \pm 0.02$ & $-1.36 \pm 0.02$ \\
\hline
\end{tabular}

${ }^{1}$ Experimental diet code indicating DDGS in diet $(0 \%, 10 \%, 20 \%$, and $30 \%$, respectively)

${ }^{2}$ Values in the same row with different superscripts are significantly different $(P<0.05, n=5)$

$\mathrm{L}^{*}$, lightness; $\mathrm{a}^{*}$, redness; $\mathrm{b} *$, yellowness; C, brightness; $\mathrm{H}$, hue

The results of the skin and fillet color measurements at the end of the 84 day experiment are given in Tables 5 and 6 . According to the opercular site skin color measurements, as well as in the fillet color measurements, all $\mathrm{L}^{*}, \mathrm{a}^{*}, \mathrm{~b}^{*}, \mathrm{C}^{*}$, and $\mathrm{H}^{*}$ values among groups were not statistically significant $(P>0.05)$, while only the $L^{*}$ value of the skin color measurements at the dorsal and caudal sites were statistically different compared to the experimental groups DDGS10 and the control $(P<0.05)$.

Table 5. Color parameters of rainbow trout skin fed the experimental diets

\begin{tabular}{|c|c|c|c|c|}
\hline \multirow[b]{2}{*}{ Parameters } & \multicolumn{4}{|c|}{ Experimental diets ${ }^{1}$} \\
\hline & Control & DDGS10 & DDGS20 & DDGS30 \\
\hline \multicolumn{5}{|l|}{ Opercular } \\
\hline$L^{*}$ & $51.74 \pm 4.69$ & $44.57 \pm 3.88$ & $51.45 \pm 5.71$ & $48.91 \pm 0.11$ \\
\hline$a^{*}$ & $3.41 \pm 1.13$ & $3.46 \pm 1.30$ & $3.25 \pm 0.66$ & $3.65 \pm 0.67$ \\
\hline$b^{*}$ & $5.44 \pm 2.46$ & $4.53 \pm 2.28$ & $6.60 \pm 0.75$ & $6.04 \pm 0.62$ \\
\hline$C^{*}$ & $6.66 \pm 1.66$ & $6.04 \pm 1.00$ & $7.36 \pm 0.92$ & $7.08 \pm 0.65$ \\
\hline $\mathrm{h} *$ & $0.96 \pm 0.33$ & $0.87 \pm 0.43$ & $1.12 \pm 0.06$ & $1.03 \pm 0.09$ \\
\hline \multicolumn{5}{|l|}{ Dorsal site } \\
\hline$L^{*}$ & $35.67 \pm 2.45^{\mathrm{a}}$ & $29.75 \pm 1.90^{b}$ & $33.92 \pm 2.05^{\mathrm{ab}}$ & $32.85 \pm 2.56^{\mathrm{ab}}$ \\
\hline$a^{*}$ & $-0.03 \pm 1.26$ & $-0.09 \pm 0.42$ & $-0.85 \pm 0.45$ & $-0.14 \pm 0.88$ \\
\hline$b^{*}$ & $5.27 \pm 1.22$ & $4.62 \pm 0.54$ & $5.45 \pm 0.37$ & $4.78 \pm 0.95$ \\
\hline $\mathrm{C}^{*}$ & $5.38 \pm 1.14$ & $4.63 \pm 0.54$ & $5.52 \pm 0.42$ & $4.83 \pm 0.95$ \\
\hline $\mathrm{h}^{*}$ & $0.55 \pm 1.55$ & $0.54 \pm 1.73$ & $-1.42 \pm 0.07$ & $-0.48 \pm 1.63$ \\
\hline \multicolumn{5}{|l|}{ Caudal site } \\
\hline$L^{*}$ & $55.79 \pm 1.80^{\mathrm{a}}$ & $47.15 \pm 4.40^{b}$ & $52.80 \pm 3.64^{\mathrm{ab}}$ & $51.14 \pm 1.67^{\mathrm{ab}}$ \\
\hline$a^{*}$ & $3.20 \pm 1.01$ & $3.28 \pm 0.51$ & $1.93 \pm 1.00$ & $3.53 \pm 0.59$ \\
\hline$b^{*}$ & $5.53 \pm 1.79$ & $6.13 \pm 1.65$ & $6.72 \pm 0.61$ & $6.33 \pm 0.86$ \\
\hline$C^{*}$ & $6.45 \pm 1.76$ & $7.02 \pm 1.21$ & $7.06 \pm 0.34$ & $7.27 \pm 0.74$ \\
\hline $\mathrm{h}^{*}$ & $1.03 \pm 0.16$ & $1.06 \pm 0.18$ & $1.29 \pm 0.16$ & $1.06 \pm 0.10$ \\
\hline
\end{tabular}

${ }^{1}$ Experimental diet code indicating DDGS in diet (0\%, 10\%, 20\%, and 30\%, respectively)

${ }^{2}$ Values in the same row with different superscripts are significantly different $(P<0.05)$. Data represent the mean of three replicates per dietary treatments, $n=15$ for each treatment. L*, intensity of lightness; $a^{*}$, redness; $b^{*}$, yellowness; $\mathrm{C}$, chroma; $\mathrm{H}$, hue 
Meat quality of rainbow trout fed diets containing DDGS

Table 6. Color parameters of rainbow trout fillet fed the experimental diets

\begin{tabular}{|c|c|c|c|c|}
\hline \multirow[b]{2}{*}{ Parameters ${ }^{2}$} & \multicolumn{4}{|c|}{ Experimental diets $^{1}$} \\
\hline & Control & DDGS10 & DDGS20 & DDGS30 \\
\hline \multicolumn{5}{|l|}{ Opercular } \\
\hline$L^{*}$ & $62.50 \pm 1.66$ & $66.11 \pm 1.95$ & $63.26 \pm 1.37$ & $64.31 \pm 2.31$ \\
\hline a* & $3.16 \pm 1.03$ & $2.78 \pm 0.16$ & $3.00 \pm 0.72$ & $3.83 \pm 0.25$ \\
\hline$b^{*}$ & $5.89 \pm 0.48$ & $5.26 \pm 0.23$ & $5.31 \pm 0.31$ & $5.79 \pm 0.21$ \\
\hline$C^{*}$ & $6.71 \pm 0.91$ & $5.95 \pm 0.20$ & $6.12 \pm 0.51$ & $6.94 \pm 0.27$ \\
\hline $\mathrm{h} *$ & $1.09 \pm 0.10$ & $1.08 \pm 0.03$ & $1.06 \pm 0.10$ & $0.99 \pm 0.03$ \\
\hline \multicolumn{5}{|l|}{ Caudal site } \\
\hline$L^{*}$ & $56.36 \pm 0.95$ & $58.66 \pm 0.84$ & $55.33 \pm 2.63$ & $57.67 \pm 1.77$ \\
\hline a* & $3.64 \pm 1.49$ & $3.17 \pm 1.31$ & $3.52 \pm 0.75$ & $3.25 \pm 0.08$ \\
\hline$b^{*}$ & $4.67 \pm 0.55$ & $4.14 \pm 0.53$ & $4.30 \pm 1.31$ & $5.73 \pm 0.56$ \\
\hline$C^{*}$ & $5.98 \pm 1.22$ & $5.27 \pm 1.13$ & $5.59 \pm 1.29$ & $6.59 \pm 0.49$ \\
\hline $\mathrm{h} *$ & $0.93 \pm 0.17$ & $0.94 \pm 0.16$ & $0.87 \pm 0.14$ & $1.06 \pm 0.04$ \\
\hline \multicolumn{5}{|c|}{$\begin{array}{l}{ }^{1} \text { Experimental diet code indicating DDGS in diet }(0 \%, 10 \%, 20 \% \text {, and } 30 \% \text {, } \\
\text { respectively) } \\
2 \text { No significant difference among means according to one-way variance analysis } \\
(\mathrm{P}>0.05) \text {. Data represent the mean of three replicates per dietary treatments, } \mathrm{n} \\
=15 \text { for each treatments. L*, lightness; } \mathrm{a}^{*} \text {, redness; } \mathrm{b}^{*} \text {, yellowness; } \mathrm{C} \text {, } \\
\text { chroma; } \mathrm{H} \text {, hue }\end{array}$} \\
\hline
\end{tabular}

\section{Discussion}

According to the results of our study, no negative effects of DDGS use as a partial replacement for FM on the rainbow trout whole body composition values (moisture, crude protein, crude lipid and crude ash) were found (Table 2). These results are in agreement with the findings of Barnes et al. (2012), and Aydın and Gümüş (2013).

Fish fatty acid composition is generally accepted to be affected by the fatty acid composition of the feed (Francesco et al., 2004; Borquez et al., 2011). This view is supported by the results of the present study (Table 3). Use of ethanol production byproduct DDGS as a protein source in place of decreasing amounts of $F M$, is shown to be effective on some rainbow trout fatty acid composition parameters, while apparently not effective on some fatty acids (Table 3 ). Lipid content of DDGS is about $10 \%$, linoleic acid (C18:2n-6) being the dominant fatty acid species $(55.7 \%$ of total fatty acids), followed by the moderate levels of oleic acid (C18: $1 n-9)$ at $25.0 \%$, palmitic acid $(\mathrm{C} 16: 0)$ at $14.9 \%$ and linolenic acid (C18:3n-3) at 7.8\% (Aydın and Gümüş, 2016). Fatty acids of FM, the most frequently used raw material in fish feeds, is largely composed of palmitic acid (22\%), oleic acid (C18:1n-9) (11\%), docosahexaenoic acid (DHA; C22:6n-3, 18\%) and eicosapentaenoic acid (EPA; C20:5n-3, 12\%) (Gümüş and Aydın, 2013). Considering the fatty acid compositions of the protein sources DDGS and FM, this study shows that replacement of FM with increasing amounts of DDGS led to a significant increase in linoleic acid content, largely due to the high linoleic acid content of DDGS (Hanson et al., 2012). Similarly, the increase in the carcass linoleic acid content with the addition of alternative protein source replacement of FM was also reported by Francesco et al. (2004), Gümüş and Aydın (2013), and Aydın et al. (2015), although no change was reported by Borquez et al. (2011). SFA and $\Sigma$ SFA values in this study were not affected by the relative decrease of FM and the increase of DDGS. Increased carcass palmitic acid and palmiteloic acid (C16:1) values were reported in Atlantic salmon (Salmo salar) after treatment with a plant protein source mix (Corn gluten and soy concentrate) as a partial replacement for FM; these changes were attributed to lowered feed consumption in addition to the relative increase in the plant protein sources in feed (Pratoomyot et al. 2010). In the present study, feed consumption did not decrease in the DDGS groups. The significant decrease in $\mathrm{n}-3$ series polyunsaturated acid eicosapentaenoic acid is in agreement with the findings of Cabral et al. (2013), Hu et al. (2013), and Aydın et al. (2015). Despite a slight decrease in eicosapentaenoic acid, no significant change corresponding to the relative increase of DDGS rate was observed in docosahexaenoic acid. However, no significant difference in eicosapentaenoic acid values between the 
Aydin et al.

control and DDGS30 could be detected in response to the decrease in FM and fish oil ratio, along with the increase of protein source DDGS. Docosahexaenoic acid like groups, $\Sigma \mathrm{n}-3$ PUFA and $\Sigma \mathrm{n}-3$ PUFA/ $\Sigma$ n- 6 PUFA, were also not affected by supplementation of DDGS. In addition, use of lupin meal as a replacement of FM in rainbow trout feed had no negative effects on muscle eicosapentaenoic acid, docosahexaenoic acid, $\Sigma$ n- 3 PUFA and $\Sigma$ n-3 PUFA/ $\Sigma$ n- 6 PUFA values (Borquez et al., 2011). As seen in Table 3, DDGS increase led to a slight decrease in $\Sigma$ n- 3 PUFA/ $\Sigma n-6$ PUFA values, and caused an increase in the $\Sigma n-6$ PUFA value. The absence of a significant drop in $\Sigma n-3$ PUFA in DDGS including experimental feeds may be linked to higher amounts of FM (minimum $54.2 \%$ in diet) or lower amount of DDGS (max. 30.0\%). Increase in the muscle $\Sigma n-6$ PUFA value along with the increase of DDGS amount should be linked with proportional increase of linoleic acid found in great amounts in DDGS. Similarly, an increase in $\Sigma n-6$ PUFA of rainbow trout carcass with the increase in vegetal protein source was reported by Francesco et al. (2004). In another study, although there was a reduction in $\sum n-3$ PUFA $/ \Sigma n-6$ PUFA ratio with the rise of linoleic acid and $\Sigma n-6$ PUFA values of rainbow trout liver correlated to the increase of the canola meal which replaced and lowered FM content. In addition, no negative impact of canola meal on $\Sigma \mathrm{n}-3$ PUFA was found (Shafaeipour et al. 2008).

The b* value of DDGS used as the alternative protein source in this study, was significantly higher than that of FM (Table 4), but this was not reflected on the skin (Table 5) and fillet (Table 6) coloration parameters ( $\mathrm{L}^{*}, \mathrm{a}^{*}, \mathrm{~b}^{*}, \mathrm{C}^{*}$, and $\mathrm{H}^{*}$ ) of the fish at the end of the trial period. However, according to the skin color measurements of the fish at operculum and caudal sites, there was a slight increase in the b* of the experimental groups as compared to the control. The addition of sea urchin as the feed supplement had no significant effect on the skin color of the red porgy (Pagrus pagrus), according to the study of García-Romero et al. (2014). Full replacement of FM in the diet of the experimental group (63.8\% of the diet) with a mixture of plant protein sources (corn gluten, wheat gluten, extruded peas, and rapeseed) resulted in a significant increase in $\mathrm{b}^{*}$ and $\mathrm{H}^{*}$ values in the fillets of the rainbow trout fed the experimental feed as compared to the control, while a* value decreased, and on the other hand no change for $L^{*}$ and $C^{*}$ was reported (Francesco et al. 2004). On the contrary, an increase in $a^{*}, b^{*}$, $\mathrm{C}^{*}$, and $\mathrm{H}^{*}$ values in the fillets due to the oleoresin paprika use in rainbow trout feed, with no significant change in the $L^{*}$ value was reported (Yesilayer and Erdem 2011). There were increased fillet $a^{*}$ values, while no significant change in $L^{*}$ and $b^{*}$ values as a response to bacterial pigment use in Nile tilapia feed (Grassi et al. 2016). Increased skin color $\mathrm{L}^{*}, \mathrm{a}^{*}, \mathrm{~b}^{*}, \mathrm{C}^{*}$, and $\mathrm{H}^{*}$ values of red porgy, fed for 120 days trial with feed which included shrimp shell meal at a rate of $16 \%$ as compared to the control, were found (Kalinowski et al. 2007). Spirulina as an additive was reported to be effective in improving the skin color of gold fish (Carassius auratus) and kenyi cichlids Maylandia lombardoi (James et al., 2009; Karadal et al., 2016). Fish skin and fillet color are affected by the types of raw materials used as additives, relative ratios applied, and the fish species used (Kalinowski et al. 2007; Yi et al. 2015; Karadal et al. 2016). According to the results of the present study, substitution of protein source by DDGS at a maximum of $30 \%$ resulted in an increase in skin color b* value only at operculum and caudal sites, while the dorsal site and fillet color values were not affected.

In conclusion, the coloration of rainbow trout skin and fillets were not modified negatively by the use of DDGS protein sources in diets. Despite a slight decrease in fish muscle fatty acid $\Sigma$ n-3 PUFA/ $\Sigma$ n- 6 PUFA value, it has been concluded that DDGS can be used in rainbow trout feed at rates up to $30 \%$ with no decrease in docosahexaenoic acid, $\sum$ n-3 PUFA, $\Sigma$ n- 6 PUFA and $\Sigma$ PUFA values.

\section{Acknowledgements}

This paper was produced from a part of the doctoral thesis of the first author and financed by the project (grant number 2014.03.0121.015) with the support of The Scientific Research Projects Coordination Unit of Akdeniz University. 


\section{References}

Aydın B. and E. Gümüş, 2013. Replacement of fish meal by poultry by-product meal with lysine, methionine and threonine supplementation to practical diets for Nile tilapia fry (Oreochromis niloticus). Isr. J. Aquacult.-Bamidgeh, IJ A_65.2013.885.

Aydın B., Gümüş E. and A. Balcı, 2015. Effect of dietary fish meal replacement by poultry by-product meal on muscle fatty acid composition and liver histology of fry of Nile tilapia, Oreochromis niloticus (Actinopterygii: Perciformes: Cichlidae). Acta Ichthyol. Piscat., 45: 343-351.

Aydın B. and E. Gümüş, 2016. Alternative feed ingredients in fish diets: Distiller's dried grains with solubles. J Anatolian Environ Anim Sci., 1 (3): 87-91.

AOAC (Association of Official Analytical Chemists), 1995. Official methods of analysis. 16th ed., Association of Official Analytical Chemists International, Arlington, VA, USA.

Barnes M.E., Brown M.L. and K.A. Rosentrater, 2012. Initial observations on the inclusion of high protein distillers dried grain into rainbow trout diets. Open Fish Sci. J., 5: 21-29.

Borquez A., Serrano E., Dantagnan P., J aime C. and H. Adrian, 2011. Feeding high inclusion of whole grain white lupin (Lupinus albus) to rainbow trout (Oncorhynchus mykiss): effects on growth, nutrient digestibility, liver and intestine histology and muscle fatty acid composition. Aquac. Res., 42: 1067-1078.

Cabral E.M., Fernandes T.J.R., Campos S.D., Castro-Cunha M., Oliveira M.B.P.P., Cunha L.M. and L.M.P. Valente, 2013. Replacement of fish meal by plant protein sources up to $75 \%$ induces good growth performance without affecting flesh quality in ongrowing Senegalese sole. Aquaculture, 380-383: 130-138.

CIE (The International Commission on Illumination), 1976. Official recommendations on uniform colour space, colour difference equations and metric colour terms. Suppl. No. 2, Publication No.15. Commission International de l'Eclairage, Paris.

Cortes-Cuevas A., Ramírez-Estrada S., Arce-Menocal J., González E. and C. López-Coello, 2015. Effect of feeding low-oil ddgs to laying hens and broiler chickens on performance and egg yolk and skin pigmentation. Rev. Bras. Cienc. Avic., 17: 247-254.

Czesny S. and K. Dabrowski, 1998. The effect of egg fatty acid concentrations on embryo viability in wild and domesticated walleye (Stizostedion vitreum). Aquat. Living Resour., 11: 371-378.

Folch J., Lees M. and G.H.S. Stanley, 1957. A simple method for the isolation and purification of total lipides from animal tissues. J. Biol. Chem., 226: 497-509.

Francesco M., Parisi G., Médale F., Lupi P., Kaushik S.J. and B.M. Poli, 2004. Effect of long-term feeding with a plant protein mixture based diet on growth and body/fillet quality traits of large rainbow trout (Oncorhynchus mykiss). Aquaculture, 236: 413-429.

García-Romero J., Ginés R., I zquierdo M.S., Haroun R., Badilla R. and L. Robaina, 2014. Effect of dietary substitution of fish meal for marine crab and echinoderm meals on growth performance, ammonia excretion, skin colour, and flesh quality and oxidation of red porgy (Pagrus pagrus). Aquaculture, 422-423: 239-248.

Grassi T.L.M., Espírito Santo E.F., Siqueira Marcos M.T., Cavazzana J.F., Oliveira D.L., Carvalho Bossolani I.L. and E.H. Giglio Ponsano, 2016. Bacterial pigment for Nile tilapia feeding. Aquac. Int., 24: 647-660.

Gümüş E. and B. Aydın, 2013. Effect of poultry by-product meal on growth performance and fatty acid composition of carp (Cyprinus carpio) fry. Turk. J. Fish. Aquat. Sci., 13: 827-834.

Hanson A.R., Xu G., Li M., Whitney M.H. and G.C. Shurson, 2012. Impact of dried distillers grains with solubles (DDGS) and diet formulation method on dry matter, calcium, and phosphorus retention and excretion in nursery pigs. Anim. Feed Sci. Technol., 172: 187-193.

Hu L., Yun B., Xue M., Wang J., Wu X., Zheng Y. and Y. Han, 2013. Effects of fish meal quality and fish meal substitution by animal protein blend on growth performance, flesh quality and liver histology of Japanese seabass (Lateolabrax japonicus). Aquaculture, 372-375: 52-61. 
Hunt R.W.G., 1977. The specification of colour appearance: I. Concepts and terms. Color Res. Appl., 2: 55-68.

James R., Vasudhevan I. and K. Sampath, 2009. Interaction of spirulina with different levels of vitamin $\mathrm{E}$ on growth, reproduction, and coloration in goldfish (Carassius auratus). Isr. J. Aquacult.-Bamidgeh, 61(4): 330-338.

Kalinowski C.T., Robaina L.E., Fernández-Palacios H., Schuchardt D. and M.S. I zquierdo, 2005. Effect of different carotenoid sources and their dietary levels on red porgy (Pagrus pagrus) growth and skin colour. Aquaculture, 244, 223-231.

Kalinowski C.T., Izquierdo M.S., Schuchardt D. and L.E. Robaina, 2007. Dietary supplementation time with shrimp shell meal on red porgy (Pagrus pagrus) skin colour and carotenoid concentration. Aquaculture, 272: 451-457.

Kalinowski C.T., Robaina L.E. and M.S. Izquierdo, 2011. Effect of dietary astaxanthin on the growth performance, lipid composition and post-mortem skin colouration of red porgy Pagrus pagrus. Aquac. Int., 19: 811-823.

Karadal O., Güroy D. and G. Türkmen, 2016. Effects of feeding frequency and spirulina on growth performance, skin coloration and seed production on kenyi cichlids (Maylandia lombardoi). Aquac. Int., 1-14.

Magalhães R., Coutinho F., Pousão-Ferreira P., Aires T., Oliva-Teles A. and H. Peres, 2015. Corn distiller's dried grains with solubles: Apparent digestibility and digestive enzymes activities in European seabass (Dicentrarchus labrax) and meagre (Argyrosomus regius). Aquaculture, 443: 90-97.

Metcalfe L.D. and A.A. Schmitz, 1961. The rapid preparation of fatty-acid esters for gas chromatographic analysis. Anal. Chem., 33: 363-364.

NRC (National Research Council), 2011. Nutrient requirements of fish. National Academy Press, Washington, USA.

Pratoomyot J., Bendiksen E.Å., Bell J.G. and D.R. Tocher, 2010. Effects of increasing replacement of dietary fishmeal with plant protein sources on growth performance and body lipid composition of Atlantic salmon (Salmo salar L.). Aquaculture, 305: 124-132.

Schaeffer T.W., Brown M.L., Rosentrater K.A. and K. Muthukumarappan, 2010. Utilization of diets containing graded levels of ethanol production co-products by Nile tilapia. Anim. Physiol. Anim. Nutr., 94: 348-354.

Shafaeipour A., Yavari V., Falahatkar B., Maremmazi J .G. and E. Gorjipour, 2008. Effects of canola meal on physiological and biochemical parameters in rainbow trout (Oncorhynchus mykiss). Aquac. Nutr., 14(2): 110-119.

Yesilayer N. and M. Erdem, 2011. Effects of oleoresin paprika (Capsicum annum) and synthetic carotenoids (canthaxantin and astaxanthin) on pigmentation levels and growth in rainbow trout. J. Anim. Vet. Adv., 10: 1875-1882.

Yi X., Li J., Xu W., Zhou H., Smith A.A., Zhang W.W. and K. Mai, 2015. Shrimp shell meal in diets for large yellow croaker Larimichthys croceus: Effects on growth, body composition, skin coloration and anti-oxidative capacity. Aquaculture, 441: 45-50.

Yigit N.O. and T. Demir, 2016. Use of fermented soybean meal with whey as a protein source for feeding juvenile tilapia (Oreochromis niloticus). Isr. J. Aquacult.-Bamidgeh, IJA_68.2016.1340. 